tissue, and an extensive bibliography. It is, accordingly, more potentially useful as a source of reference than the other sections. The discussion of the application of stable isotopes includes descriptions of the mass spectrometer, but not of the densimetric method for the analysis of deuterium and oxygen-18, being content with reference to another work.

The subject of radioactive tracers has been dealt with in several volumes recently, and it is obvious that in fifty pages only limited information may be given. The Lauritsen electroscope is described at some length. There is the almost inevitable sketch of a bell-type Geiger-Müller counter, but no mention of counters for liquid samples, which are of common occurrence in biological work. Nothing is said of the correction which has to be made for dead time of the counting equipment, although other corrections are discussed. Mention might be made of the application of radioactive tracers in chromatography.

In conclusion, I feel that this book should be useful to the student of M.Sc. standard, who wants an introductory survey of some of the physical methods of attacking problems. It is not, nor does it claim to $\mathrm{be}$, a book of reference for practical laboratory work.

E. J. HARRIS

\section{SELECTION OF LEADERS IN WAR-TIME}

The Group Approach to Leadership-Testing By Dr. Henry Harris. Pp. $x+288$. (London: Routledge and Kegan Paul, Ltd., 1949.) 21s. net.

$T$ is well known that during the Second World War I the British Army developed a somewhat elaborate procedure for the selection by special boards of potential officers. In this book Dr. Henry Harris gives a reasonably full and detailed account of the practices that were adopted and of how and why they were used.

It is interesting and possibly significant that the account begins by a discussion of 'theories'. Maybe this is merely a matter of convenience in exposition; but it is hard to escape from the impression that, first, a general and very speculative view of personality and group functions and relations was accepted (mainly in terms of the 'field theory' of Lewin and others, with a strong mixture of general psychiatry, perhaps largely of a Freudian type) and then all sorts of ingenious ways of illustrating this view in concrete situations were organised and applied. If this is what happened, nobody has any right to complain, for the conditions were urgent and the time short. But the basic problem of how to find sectional leaders remains as important in peace as in war, and, if it is implied that the procedure adopted should remain a model for all subsequent approach, difficulties are bound to arise.

Obviously the justification of any selection procedure must rest mainly upon validation. A ehapter on validation of the War Office Selection Board methods, written by Major Gavin Reeve, is included in this book; but it is not satisfactory. It does show that the verdicts reached were, by the accepted statistical criteria, reasonably reliable; but that is not enough, especially in view of the very uniform training given to the essential officers of the selection boards. It shows also that training wastage was substantially reduced, and this, in the circumstances, is a great and important point in favour of the general scheme. But it does not, and indeed cannot, show whether the leaders selected were in later trial significantly better than those picked out in any other way. That this is a critically difficult task anybody with experience, even in much more defined fields of personnel selection, will at once agree ; but it is a task that must be attempted when there is time, for it will certainly never be accom. plished in an atmosphere of crisis.

On a descriptive level, the book is extremely interesting and well written. It reveals a carefully planned and conducted effort which deserves all the praise-and perhaps some of the blame-which it has received. Very appreciative comments by Sir Ronald Adam and Brigadier Torrie are included, and these two are, beyond doubt, among those who should know.

F. C. BarthetT

\section{ARCH/EOLOGY OF THE BADEGOULE SITE}

Badegoule, Station solutréenne et proto-magdalénienne

Par Dr. André Cheynier. (Archives de l'Institut de Paléontologie humaine, Mémoire 23.) Pp. iii +230 . (Paris : Masson et Cie., 1949.) 2500 francs.

THE prehistoric site at Badegoule has been known for a long time. Indeed, so long ago as 1906 it was described by Drs. Paul Girod and Massénat, and a section given. These investigators realized that here was an important Solutrean station worthy to be classed with Laugerie Haute. M. Peyrony dug there, and an account of his finds appeared in the Revue Préhistorique for 1908. Hauser and the Abbé Bouyssonie also examined the place; but for the period 1928-39 the site was systematically studied by Dr. André Cheynier, who, as a local medical practitioner, was able to give it his continuous attention.

At the base there is evidence of sporadic occupation by Mousterian folk, though the rarity of the finds and the absence of hearths has led Dr. Cheynier to the conclusion that the Mousterians never made the place into a real home. But the importance of Badegoule lies in the extensive Solutrean layers occurring there-no less than six levels. They date from Proto-Solutrean to the latest Upper Solutrean and so give a full range of the culture. Over the latest Solutrean occur two Proto-Magdalenian levels; but these are of no especial interest. The volume is exceptionally well illustrated and will be indispensable to any student interested in the Solutrean 'episode'.

A number of poor engravings, mostly on stone, were found; to what extent the Solutreans themselves were artists, or how far the comparatively few works of art found in their levels were the work of the surviving Aurignacian folk dominated by the invading Solutreans, has long been a problem. It is only fair to say that at Badegoule quite a number of examples have been found, and the levels concerned appear to be purely Solutrean in character. The art is poor and there is much 'scrabbling'; but one or two better-drawn examples of animal figures can be noted.

It is obvious that the explorations and the publication have been a labour of love continuing for many years, and it is excellent that these painstaking and methodical studies are here so well recorded.

M. C. BURKITT 